\title{
Immunostimulatory Effect of Zanthoxylum schinifolium-Based Complex Oil Prepared by Supercritical Fluid Extraction in Splenocytes and Cyclophosphamide-Induced Immunosuppressed Rats
}

\author{
Hak Yong Lee, ${ }^{1}$ Young Mi Park, ${ }^{1}$ Yang Hee Lee, ${ }^{1}$ Yang Gyu Kang, ${ }^{1}$ Hyang Man Lee, \\ Deuk Seon Park, ${ }^{2}$ Hye Jeong Yang, ${ }^{3}$ Min Jung Kim, ${ }^{3}$ and Young-Rae Lee $\mathbb{D}{ }^{1,4}$ \\ ${ }^{1}$ INVIVO Co. Ltd., 460, Iksandae-ro, Iksan, Jeonbuk 54538, Republic of Korea \\ ${ }^{2}$ Sandle Co. Ltd., 2000-89 Sincha-ro, Chahwang-myeon, Sancheong, Gyeongnam 52206, Republic of Korea \\ ${ }^{3}$ Korea Food Research Institute, 245, Nongsaengmyeong-ro, Iseo-myeon, Wanju-gun, Jeollabuk-do 55365, Republic of Korea \\ ${ }^{4}$ Department of Oral Biochemistry and Institute of Biomaterial-Implant, College of Dentistry, Wonkwang University, 460 Iksandae-ro, \\ Iksan, Jeonbuk 54538, Republic of Korea
}

Correspondence should be addressed to Young-Rae Lee; mindyr@wku.ac.kr

Received 7 June 2018; Revised 15 August 2018; Accepted 19 September 2018; Published 8 October 2018

Academic Editor: Michał Tomczyk

Copyright (C) 2018 Hak Yong Lee et al. This is an open access article distributed under the Creative Commons Attribution License, which permits unrestricted use, distribution, and reproduction in any medium, provided the original work is properly cited.

\begin{abstract}
Complex oil of Zanthoxylum schinifolium and Perilla frutescens seed (ZPCO) is used as a traditional medicine due to its pharmacological activities. The aim of this study was to investigate the immunostimulatory effect of ZPCO in isolated splenocytes as well as in an immunosuppressed rat model, which was generated via oral administration of cyclophosphamide. Notably, our results showed that ZPCO exerted an immunity-enhancing effect both in vitro and in vivo. Specifically, ZPCO treatment enhanced the viability and inflammatory cytokine production of splenocytes and NK cell activity in vitro. Moreover, this product improved host defense under immunosuppressive conditions by increasing the number of immune cells and promoting the expression of cytokines involved in immune responses. Our results suggest that complex oil including Z. schinifolium should be explored as a novel immunostimulatory agent that could potentially be used for therapeutic purposes or as an ingredient in functional foods.
\end{abstract}

\section{Introduction}

Zanthoxylum schinifolium is an aromatic plant that is widely used as a spice for cooking. Notably, the extract of this plant is also used as a crude drug for treating pain in East Asian countries [1]. Recently, several phytochemical studies conducted on $Z$. schinifolium focused on the essential oils, coumarins, flavonoids, and alkaloids in the fruits and leaves of the plant [2]. Furthermore, Z. schinifolium extracts were shown to exert various pharmacological effects, including antiplatelet aggregation [3], antioxidant [4], and antitumor activities [5], and were found to inhibit the production of monoamine oxidase [6]. Although a recent report showed that an ethanol extract of $Z$. schinifolium exerted an antiinflammatory effect on human cells [7], there have yet to be any reports on the effects of Complex oil including $Z$. schinifolium on the immune response.

The immune system comprises various organs such as the thymus, bone marrow, lymph nodes, and spleen. The body becomes prone to infections caused by invading organisms when the immune system is compromised. Thus, it is critical to identify treatments for enhancing the immune response of immunocompromised individuals to protect against infections by pathogenic organisms. In a recent study, natural plants and their immunomodulatory components were studied in an effort to discover potential immunoenhancing agents for use as ingredients in functional foods [8]

Cancer is one of the leading causes of death worldwide. Many drugs used for cancer treatment are associated with harmful side effects such as damage to the immune system 
[9]. Furthermore, chemotherapeutic strategies for cancer treatment are associated with high systemic toxicity and drug resistance, which limit treatment success in most cases [10]. Accordingly, new therapeutic strategies have been developed that do not damage the immune system of patients undergoing cancer treatment $[11,12]$, and efforts are being made to research natural compounds that can improve immunity [13]. The role of activated immune cells in the defense against cancer cells has been extensively studied. Moreover, evidence that activated immune cells recognize and eliminate cancer cells, including cancer cells resistant to drugs used for chemotherapy, has been reported $[14,15]$.

Cyclophosphamide (Cy) is a commonly used antineoplastic agent which often results in immunosuppression, myelosuppression, and cytotoxic effects [16-18]. Administration of Cy can lead to a sudden change in Th1/Th2 bias, resulting in immunosuppression [19]. In previous studies, the immunological effects of Cy were found to decrease the absolute number of T cells, proliferation of lymphocytes, Th1 cell produced cytokines (IL-2, IL-12, and IFN- $\gamma$ ), and Th2 produced cytokine (IL-4) [20].

In recent studies, much effort has been directed to discover novel natural compounds with immune-enhancing effects. The role of activated immune cells in the defense against cancer cells has been extensively studied. Moreover, it has been reported that activated immune cells recognize and eliminate cancer cells, including drug resistant cancer cells $[14,15]$. In the present study, we investigated the in vitro and in vivo immunostimulatory effects of ZPCO in isolated splenocytes and immunosuppressed rats.

\section{Materials and Methods}

2.1. Preparation of ZPCO. ZPCO was manufactured by Sandle Co. Ltd. (Sancheong-Gun, Gyeongnam, Korea). The oil was prepared as follows. Briefly, the aerial parts of $Z$. schinifolium and Perilla frutescens seed were collected from Hansalim Contract Farming complex in Sancheong, Gyeongnam, Republic of Korea, dried, and powdered. The powder of Z schinifolium (150 kg) and Perilla frutescens seed (150 kg were extracted with a supercritical CO2 extractor [21], and of extracted oil of $75 \mathrm{~L}$ was obtained. The sample was incubated at $50^{\circ} \mathrm{C}$ and 250 bars for $10 \mathrm{~min}$. Extraction was then performed by passing $\mathrm{CO}_{2}(99.9 \%)$ through the column at a flow rate of $2.0 \mathrm{ml} / \mathrm{min}$ to obtain the oil.

2.2. Sample Preparation. Fat extract: the homogenized specimen was weighed and placed in a Mojonnier tube. About $100 \mathrm{mg}$ of pyrogallol and $2 \mathrm{ml}$ of internal standard solution were added to the tube. Subsequently, boiling water, $2 \mathrm{ml}$ of ethanol, and $10 \mathrm{ml}$ of $8.3 \mathrm{M}$ hydrochloric acid solution were added and mixed well; the tube was sealed and immersed in a water bath at $70-80^{\circ} \mathrm{C}$ for $40 \mathrm{~min}$. Preparation of test solution: the fat, extracted with 2-3 $\mathrm{ml}$ chloroform and 2-3 $\mathrm{ml}$ diethyl ether, was dissolved and transferred to a $15-\mathrm{ml}$ test tube. The solution was concentrated with nitrogen at $40^{\circ} \mathrm{C}$, and $2.0 \mathrm{ml}$ of $7 \%$ trifluoroborane methanol solution and $1.0 \mathrm{ml}$ of toluene were added. The mixture was heated in a $100^{\circ} \mathrm{C}$ oven for $45 \mathrm{~min}$ and then cooled. Subsequently, $5.0 \mathrm{ml}$ of distilled water, $1.0 \mathrm{ml}$ of hexane, and about $1.0 \mathrm{~g}$ of anhydrous sodium sulfate were added, and the mixture was allowed to stand with shaking. The separated supernatant was dehydrated to prepare a test solution.

2.3. GC Analysis. ZPCO analysis was performed using a gas chromatograph (GC 7890B, Agilent Technology, USA) equipped with a flame ionization detector (FID). SP-2560 $(100 \mathrm{~m}(100 \mathrm{~m} \times 0.25 \mathrm{~mm} \times 0.2 \mathrm{~m})$ was used for column separation; the column flow was $0.75 \mathrm{ml} / \mathrm{min}$ and the split ratio was 200:1. The temperatures of the insert and the detector were $225^{\circ} \mathrm{C}$ and $285^{\circ} \mathrm{C}$, respectively. The temperature of the oven was maintained at $100^{\circ} \mathrm{C}$ for $4 \mathrm{~min}$, subsequently elevated up to $240^{\circ} \mathrm{C}$, at the rate of $3^{\circ} \mathrm{C} / \mathrm{min}$, and maintained at this temperature for $15 \mathrm{~min}$.

2.4. Animals. Five-week-old male Sprague Dawley (SD) $(n=$ 36) rats were purchased from Samtaco Inc. (Osan, Gyeonggido, Korea) and adapted to the following conditions for 7 days: 12-h light/12-h dark cycle; temperature, $23 \pm 1^{\circ} \mathrm{C}$; humidity, $50 \pm 5 \%$; and illumination, 150-300 lux. The animals were allowed ad libitum access to food (Purina diet; Purina Korea, Seongnam, Gyeonggi-do, Korea) and water. Splenocytes were collected from one rat for the study. The remaining 35 rats were then randomly assigned to five groups ( 7 rats per group). The protocols used for these animal studies were approved by the Committee on Care and Use of Laboratory Animals of Wonkwang University (Iksan, Jeollabuk-do, Korea; approval no. WKU16-19).

2.5. Cell Culture. The spleen of an 8-week-old SD rat was aseptically dissected to obtain splenocytes. The spleen was gently pressed with forceps and then forced through a 70$\mu \mathrm{m}$ cell strainer (SPL Life Sciences, Pocheon-si, Gyeonggido, Korea). The cells were collected and washed three times in Roswell Park Memorial Institute (RPMI)-1640 (Invitrogen, Carlsbad, CA, USA) by centrifugation $\left(80 \times g, 3 \mathrm{~min}, 4^{\circ} \mathrm{C}\right)$. Next, the cells were treated with red blood cell lysis buffer (Sigma-Aldrich, St. Louis, MO, USA). Isolated splenocytes were maintained in RPMI-1640 containing 10\% fetal bovine serum (FBS) and 1\% antibiotics (penicillin, streptomycin) (Invitrogen) in a $5 \% \mathrm{CO}_{2}$ incubator.

2.6. Cell Viability. Cell viability assays were performed using a WST-1 Assay Kit (ITSBio, Seoul, Gyeonggi-do, Korea), according to the manufacturer's instructions. Briefly, splenocytes $\left(2 \times 10^{5}\right.$ cells/well $)$ were seeded into 96 -well plates and incubated at $37^{\circ} \mathrm{C}$ for $4 \mathrm{~h}$ to allow for cell stabilization. Next, the cells were treated with ZPCO $(0,5,10,30,50,100$, or $300 \mu \mathrm{g} / \mathrm{ml}$ ) and cyclophosphamide $(\mathrm{CY} ; 1600 \mu \mathrm{g} / \mathrm{ml})$ or lipopolysaccharide (LPS; $10 \mu \mathrm{g} / \mathrm{ml}$ ) and incubated for $24 \mathrm{~h}$ in a $5 \% \mathrm{CO}_{2}$ incubator. Each experiment was performed in triplicate. Splenocyte viability rate was assessed using a WST1 Assay Kit and a Sunrise ${ }^{\mathrm{TM}}$ enzyme-linked immunosorbent assay (ELISA) plate reader (Tecan, Männedorf, Switzerland). 


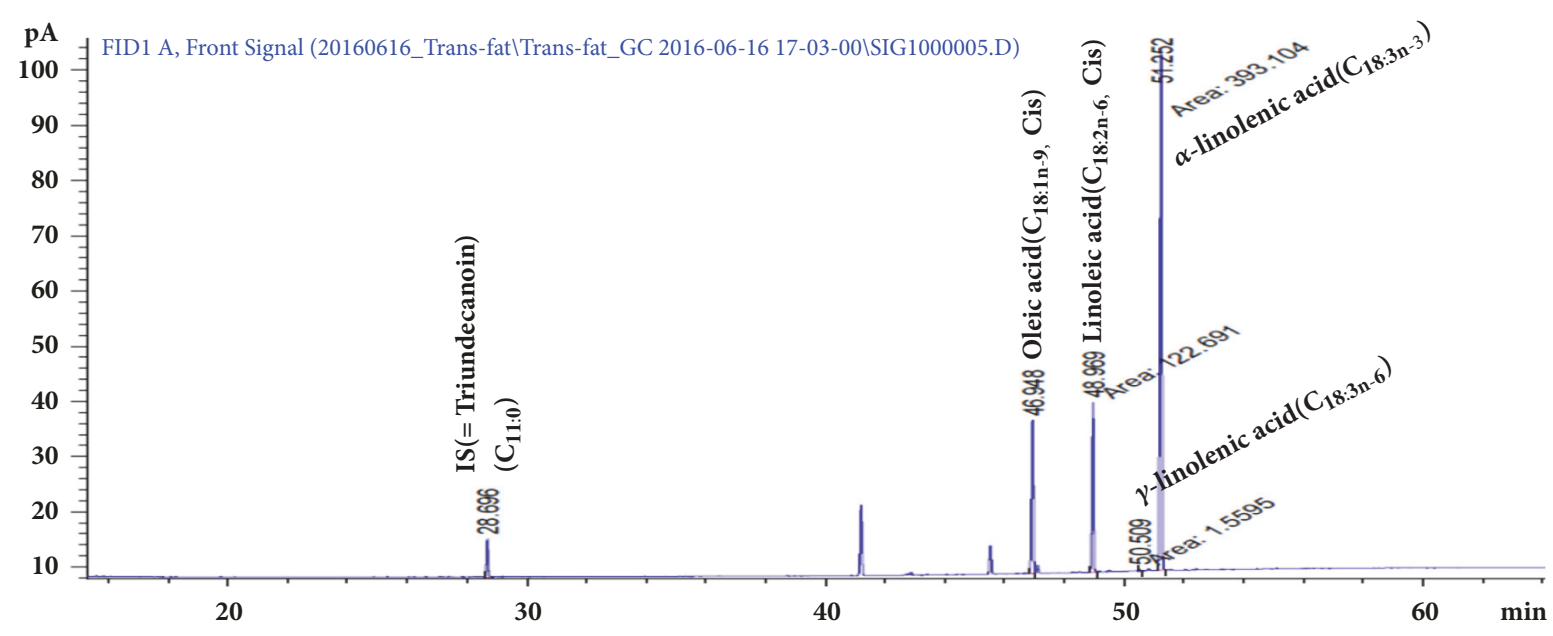

FIGURE 1: Gas chromatography profile of ZPCO. Large amounts of oleic acid, linoleic acid, and linolenic acid were detected in ZPCO.

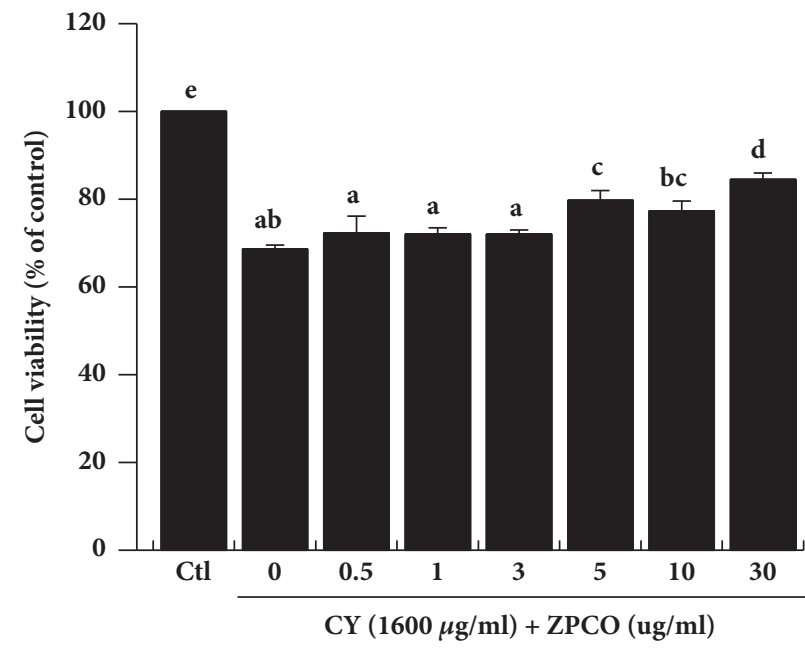

(a)

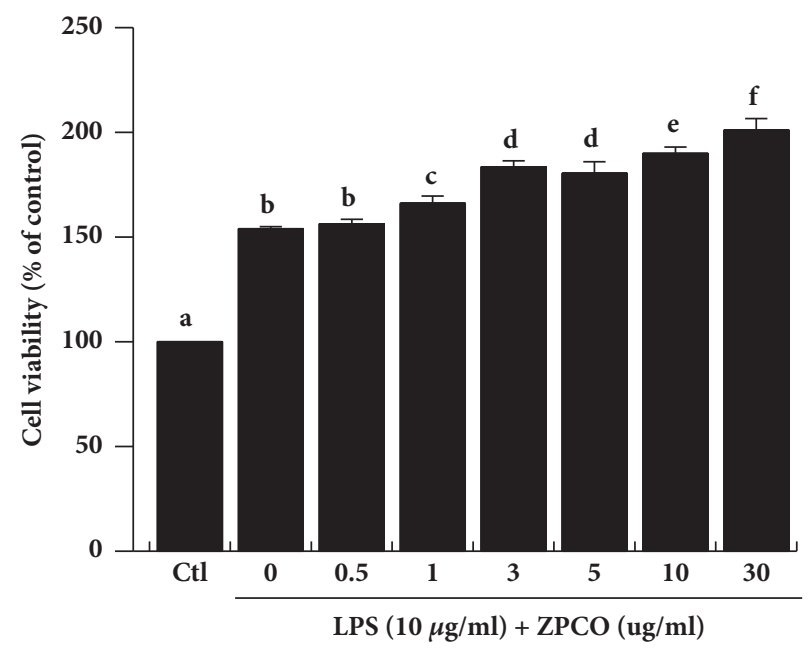

(b)

Figure 2: Effect of ZPCO on splenocyte viability. Cells were seeded into 96 -well plates, followed by treatment with ZPCO (0, 5, 10, 30, 50, 100 , or $300 \mu \mathrm{g} / \mathrm{ml}$ ) and cyclophosphamide (CY; $1600 \mu \mathrm{g} / \mathrm{ml}$ ) or lipopolysaccharide (LPS; $10 \mu \mathrm{g} / \mathrm{ml}$ ). Next, the cells were incubated for $24 \mathrm{~h}$ in a $5 \% \mathrm{CO}_{2}$ incubator, after which viability was assessed. Bars labeled with different superscripts have significantly different values $(\mathrm{P}<0.05)$. Data are presented as means \pm standard errors $(n=3)$.

2.7. NK Cell Activity Assay. YAC-1 cells obtained from the American Type Culture Collection (ATCC, Manassas, USA) were used as target cells for NK cell activity assay, and splenocytes were isolated from control or ZPCO-treated groups for use as effector cells. Splenocytes were cocultured with YAC-1 cells in 96-well plates at a ratio of effector cells to target cells $(10: 1,20: 1$, and 50:1) and cultured in a 5\% $\mathrm{CO}_{2}$ incubator at $37^{\circ} \mathrm{C}$ for $24 \mathrm{~h}$. YAC-1 viability rate was assessed using a WST-1 Assay Kit and a Sunrise ${ }^{\mathrm{TM}}$ enzymelinked immunosorbent assay (ELISA) plate reader (Tecan, Männedorf, Switzerland). The NK cell activity was calculated as the survival rate of YAC-1 compared to that of the control group.

2.8. Cytokine Levels in Splenocytes. Splenocytes $\left(2 \times 10^{5}\right.$ cells/well) were seeded into 96-well plates with RPMI-1640 containing $10 \%$ FBS and $1 \%$ antibiotics (growth media), after which ZPCO $(0,1,10,100$, or $250 \mu \mathrm{g} / \mathrm{ml})$ and LPS $(10 \mu \mathrm{g} / \mathrm{ml})$ were added to the wells. The cells were then incubated for $24 \mathrm{~h}$ in a $5 \% \mathrm{CO}_{2}$ incubator. Each experiment was performed in triplicate. The levels of tumor necrosis factor- (TNF-) $\alpha$, interferon- (IFN-) $\gamma$, interleukin- (IL-) 2, and IL-12 in the culture medium from each well were then measured using Cytokine Activation Analysis Kits (R\&D Systems, Minneapolis, MN, USA), according to the manufacturer's instructions. The results were measured using an ELISA reader.

2.9. Determination of Nitric Oxide (NO) Production. After various treatments, $\mathrm{NO}$ in the culture supernatants was measured with the addition of $100 \mu \mathrm{l}$ of Griess reagent (1\% sulfanilamide and $0.1 \% \mathrm{~N}$-[1-naphthyl]-ethylenediamine dihydrochloride in $5 \%$ phosphoric acid) to $100 \mu \mathrm{l}$ of each 


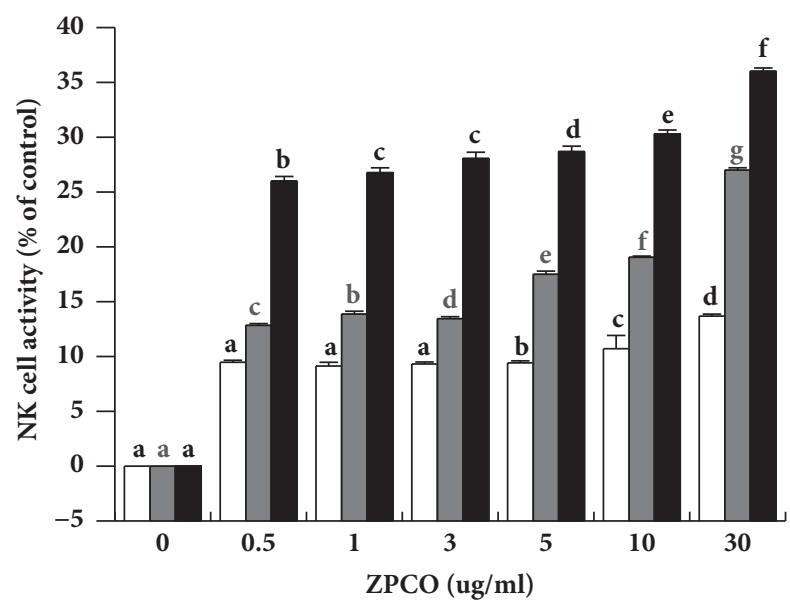

Target : Effector cell
\begin{tabular}{|l}
\hline \\
$1: 10$ \\
\hline $1: 20$ \\
$1: 50$
\end{tabular}

FIGURE 3: Effect of ZPCO on NK cell activity. Splenocytes were cocultured with target cells (YAC-1) in 96-well plates, followed by treatment with ZPCO $(0,5,10,30,50,100$, or $300 \mu \mathrm{g} / \mathrm{ml})$ and incubated for $24 \mathrm{~h}$ in a $5 \% \mathrm{CO}_{2}$ incubator with a ratio of effector to target cells of 10:1, 20:1, and 50:1. The NK cell activity was calculated as the survival rate of YAC-1 compared to that of the control group. Bars labeled with different superscripts have significantly different values $(\mathrm{P}<0.05$ versus control). Data are presented as means \pm standard errors $(\mathrm{n}=3)$.

sample. The NO concentration was determined at $540 \mathrm{~nm}$ using $\mathrm{NaNO} 2$ as a standard.

2.10. Complete Blood Count (CBC) and Cytokine Analyses. SD rats were orally administered ZPCO (0, 30, 100, or $300 \mathrm{mg} / \mathrm{kg} /$ day) and CY (5 mg/kg, once per day) for 28 days. Meanwhile, rats administered saline were used as a control group. After the final administration of the various drugs, the rats were weighed and anesthetized via intraperitoneal injection of 2,2,2-tribromoethanol (Sigma-Aldrich). Whole blood was collected through the abdominal vena cava into ethylenediaminetetraacetic acid (EDTA) microtubes. Next, the rats were sacrificed by brief exposure to $100 \% \mathrm{CO}_{2}$, followed by cervical dislocation. The numbers of white blood cells (WBCs), lymphocytes, and neutrophils in each whole blood sample were measured using a Hemavet 950 system (Drew Scientific Group, Dallas, TX, USA). In addition, midrange absolute counts (MID), which generally includes monocytes, eosinophils, and basophils, were determined. The plasma levels of TNF- $\alpha$, IFN- $\gamma$, IL-2, and IL-12 were quantified using ELISA kits (R\&D Systems), according to the manufacturer's instructions.

2.11. Histological Analysis. After the animals were sacrificed, their organs (liver, kidney, thymus, and spleen) were removed, weighed, and fixed in $10 \%$ neutral buffered formalin. The organs were then processed for embedding in paraffin, after which they were sectioned into 4-7- $\mu \mathrm{m}$ thick slices using a microtome (Thermo Scientific, Waltham, MA, USA). The sectioned tissues were then stained with hematoxylin and eosin. Tissue damage was assessed under an optical microscope (Olympus, Fukuoka, Japan).

2.12. Statistical Analysis. Results were analyzed by one-way analysis of variance (ANOVA) and Duncan's multiple range tests using SAS software (version 9.3; SAS Institute Inc., Cary, NC, USA). P values $<0.05$ were considered statistically significant.

\section{Results and Discussion}

3.1. HPLC Analysis of ZPCO. The extract was subjected to GC profiling to analyze the constituents of the ZPCO. A composition analysis of the ZPCO revealed that palmitic acid (19\%), oleic acid (35\%), linoleic acid (23\%), and linolenic acid (16\%) constituted more than $90 \%$ of fatty acid content [22]. The ZPCO extract used in this study also contains a large amount of oleic acid, linoleic acid, and linolenic acid (Figure 1). Fatty acids are implicated in pathologies, including cardiovascular disease, metabolic diseases such as cancer, diabetes, and inflammatory diseases $[23,24]$.

3.2. ZPCO Stimulates Splenocyte Viability. Proliferation of lymphocyte and macrophage is an early event in the activation of cellular and humoral immune responses. Splenocytes are composed of various cell types, including macrophages, dendritic cells, and $\mathrm{T}$ and $\mathrm{B}$ lymphocytes, which have different immune functions [15]. Generally, LPS causes activation of polyclonal B cells and stimulation of monocyte, dendritic cell, and macrophages. Furthermore, it has been reported that LPS activates T cells [25-27]. In addition, CD4 T cells have been shown to express toll-like receptor-4 (TLR4), a receptor for LPS $[28,29]$. Stimulation of splenocyte viability ultimately increases the release of cytokines, potentially explaining the immune enhancement and antitumor activity $[30,31]$. Therefore, in our study, splenocytes were incubated with CY $(1600 \mu \mathrm{g} / \mathrm{ml})$ or LPS $((10 \mu \mathrm{g} / \mathrm{ml})$, and ZPCO $(0$, $5,10,30,50,100$, or $300 \mu \mathrm{g} / \mathrm{ml})$ for $24 \mathrm{~h}$, after which cell viability was measured. This was done to assess levels of splenocyte proliferation following each treatment. Notably, ZPCO treatment increased splenocyte viability in a dosedependent manner (Figure 2). In addition, ZPCO treatment significantly attenuated the reduction in cell viability observed in splenocytes treated with CY and LPS but, ZPCO alone-treated group did not any significant change in viability (Supplementary Figure 1).

\subsection{Evaluation of the Effect of ZPCO on NK Cell Activity} Assay. NK cells are activated by stimulation of cytokines and chemokines and have been shown to play a central role in the regulation of tumor growth and metastasis [32]. NK cells are a major population of cytotoxic lymphocytes and play an important role in the defense against cancer and viruses $[33,34]$. NK cell activity assays have been used to assess the effects of functional foods on nonspecific cell-mediated 


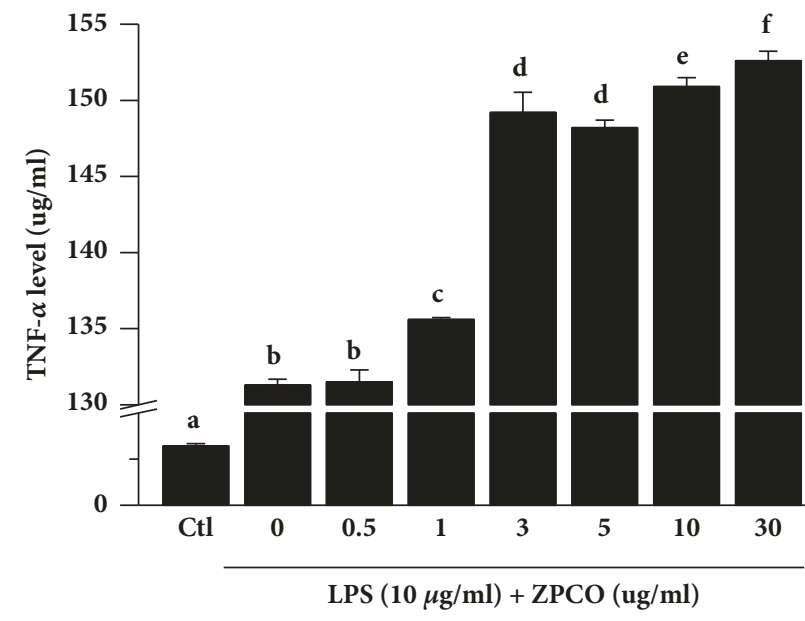

(a)

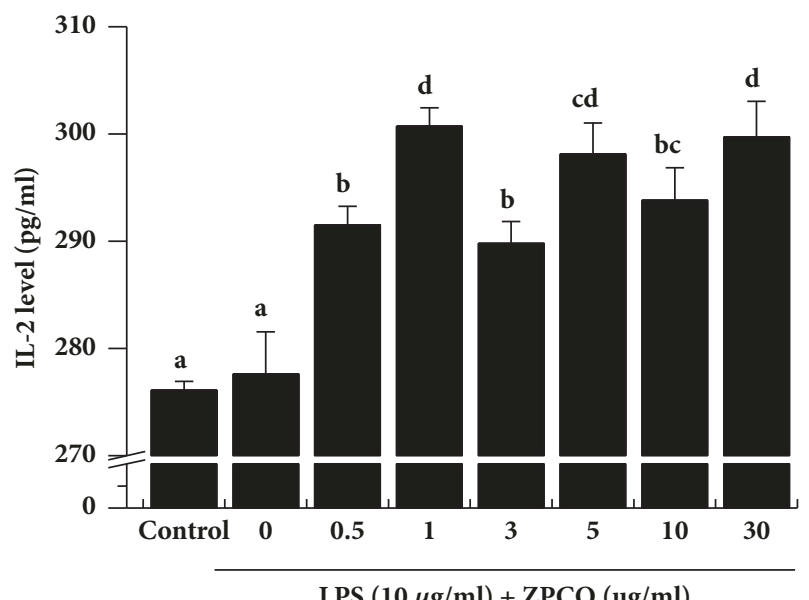

(c)

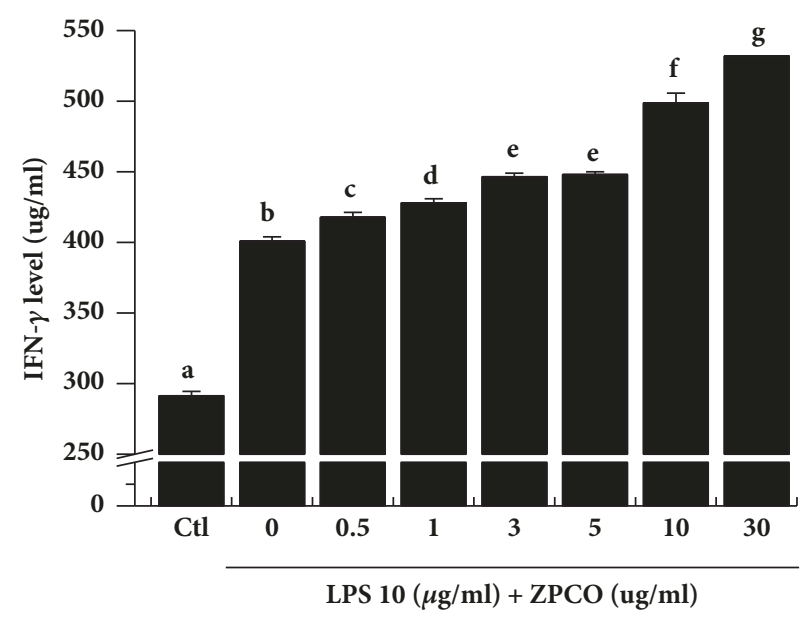

(b)

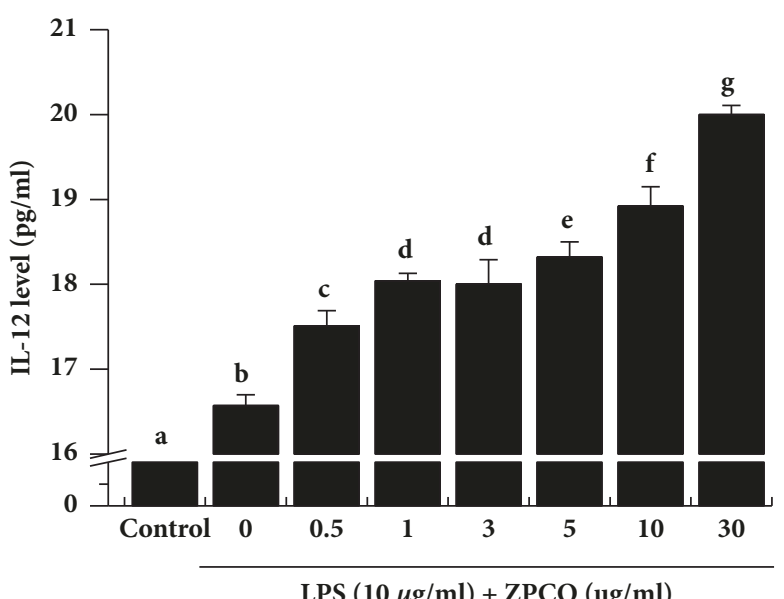

(d)

FIGURE 4: Effect of ZPCO on the concentration of cytokines in splenocytes. Cells were seeded into 96-well plates, followed by treatment with ZPCO $(0,5,10,30,50,100$, or $300 \mu \mathrm{g} / \mathrm{ml})$ or lipopolysaccharide (LPS; $10 \mu \mathrm{g} / \mathrm{ml}$ ). Next, the cells were incubated for $24 \mathrm{~h}$ in a $5 \% \mathrm{CO}_{2}$ incubator, after which the levels of TNF- $\alpha$, IFN- $\gamma$, IL-2, and IL-12 secretion into the culture medium were analyzed. Bars labeled with different superscripts have significantly different values $(\mathrm{P}<0.05$ versus control). Data are presented as means \pm standard errors $(\mathrm{n}=3)$.

immunity. Therefore, we confirmed the effects on NK cell activity by ZPCO. Splenocyte cytotoxicity was tested against NK-sensitive tumor cells (Yac-1). As shown in Figure 3, the NK cell activity was significantly increased after exposure to the ZPCO. The results indicated that the ZPCO can regulate the innate immune response against tumor cell.

\subsection{ZPCO Increases LPS-Induced Cytokine Expression in} Splenocytes. Cytokines, which play important roles in immune modulation, inflammation regulation, lymphocyte differentiation, host defense against bacterial infection, cell survival, cell death, and immune responses [35-37], are released by several immune cell types. LPS stimulates CD4+T cells and d, APCs such as monocyte, macrophages, and dendritic cells, which secrete a variety of cytokines such as IFN-1, TNF- $\alpha$, and IL-12 [25, 27, 38]. Furthermore, IL-12 plays an essential role in the differentiation of naive $\mathrm{T}$ cells into Th1 cells and activation of natural killer cells [39]. In the present study, we evaluated the in vitro effect of ZPCO on the production of cytokines associated with immune responses by incubating splenocytes with ZPCO $(0,5,10,30,50,100$, or $300 \mu \mathrm{g} / \mathrm{ml})$ and LPS $(10 \mu \mathrm{g} / \mathrm{ml})$. As shown in Figure 4, ZPCO-treated splenocytes produced higher levels of TNF- $\alpha$, IFN- $\gamma$, IL-2, and IL-12 than did the non-ZPCO-treated and control splenocyte populations. ZPCO alone-treated splenocytes slightly increased production of TNF-a, IFN-y, IL-2, and IL-12 (Supplementary figure 2).

3.5. Effect of ZPCO on NO Production in Splenocytes. Splenocyte activation can play a role in novel immunotherapeutic approaches for the treatment of cancer [15]. NO regulates host immunity as a modulator of T-lymphocyte responses. There are some controversial reports about the immunomodulation of NO. Badovinac et al. (2000) found that macrophage-derived NO had an effect in promoting IL-2-induced splenocyte growth at low concentrations [40]. 


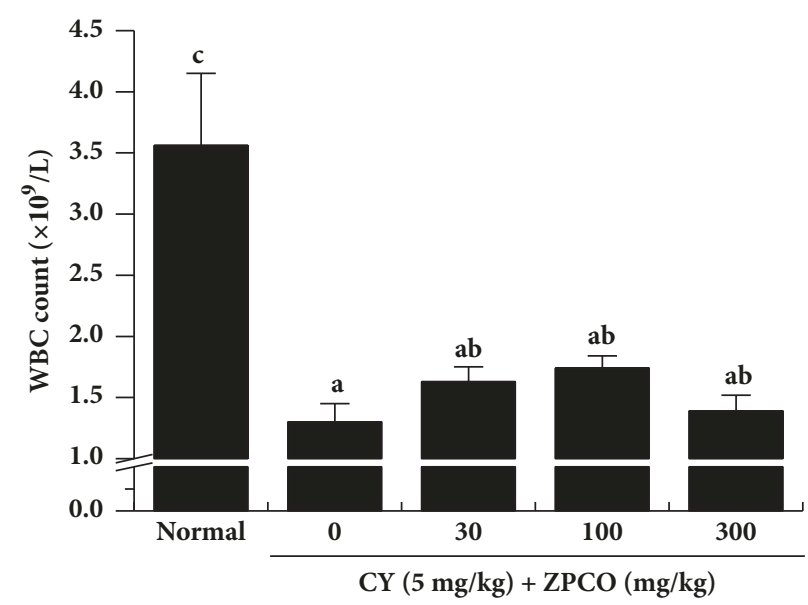

(a)

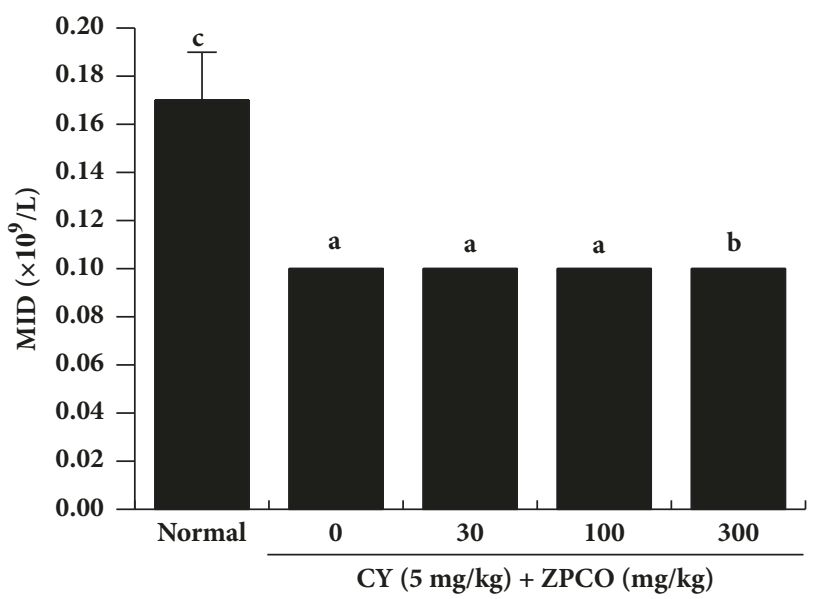

(c)

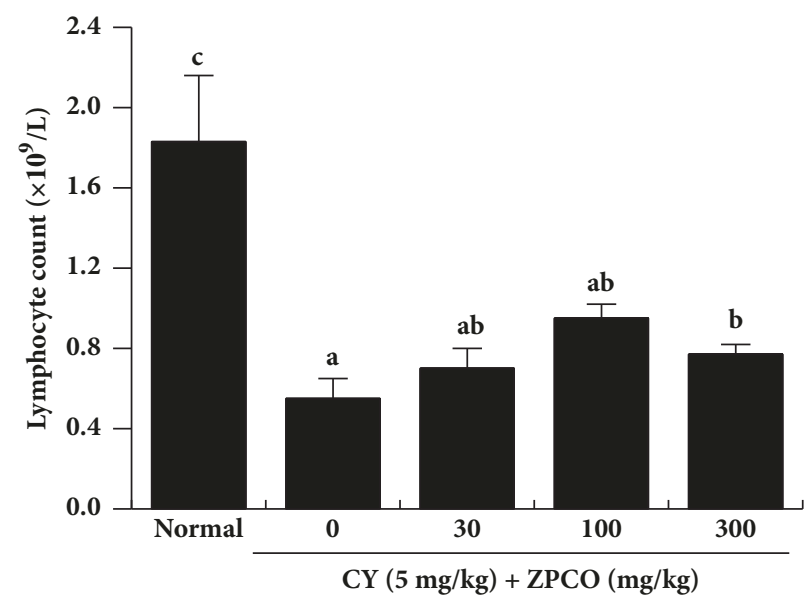

(b)

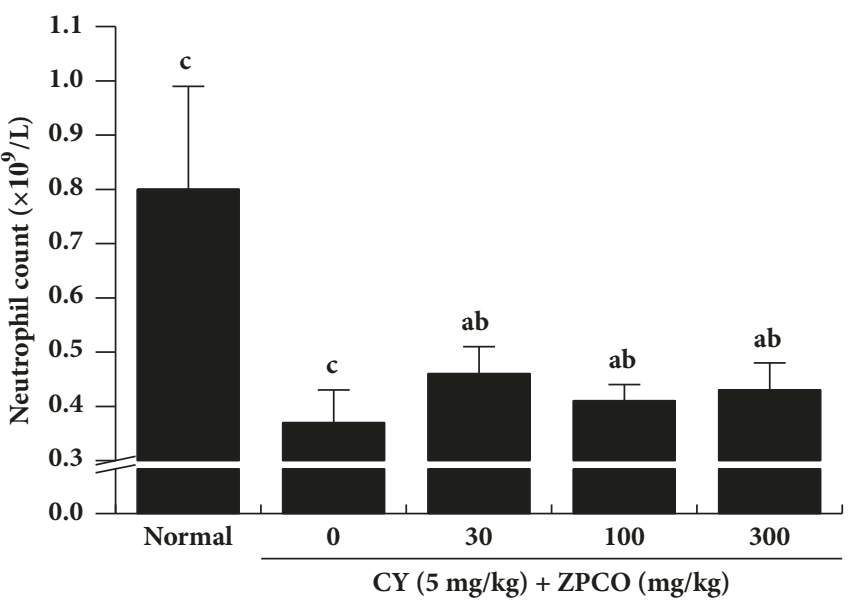

(d)

FIGURE 5: Effects of ZPCO on white blood cell (WBC), neutrophil, and lymphocyte counts and on midrange absolute counts (MID) in the whole blood of Sprague Dawley (SD) rats. SD rats were treated with saline, cyclophosphamide (CY; $5 \mathrm{mg} / \mathrm{kg} / \mathrm{day})$, and oral ZPCO (0, 30, 100 , or $300 \mathrm{mg} / \mathrm{kg} / \mathrm{day}$ ) once daily for 28 days, after which whole blood samples were collected for analysis. The levels of WBCs, neutrophils, and lymphocytes in the blood samples were determined using a Hemavet 950 system. MID was also measured. Bars labeled with different superscripts have significantly different values $(P<0.05$ versus control. Data are presented as means \pm standard errors $(n=7)$.

Therefore, we examined whether ZPCO was able to stimulate the growth and functional activation of splenocytes. We confirmed that NO reduced by $\mathrm{CY}$ is restored by ZPCO (Supplementary figure 3). This result suggests that ZPCO could activate the splenocyte-mediated immune response and growth.

3.6. ZPCO Treatment Results in Increased Numbers of Immune Cells in Rats. Immunosuppression is an indication that the defense system is not strong enough to defend a host against various infections. As people age, their immune system becomes weaker. For instance, immune tissues shrink, and the number of white blood cells decreases [41]. Immune responses are elicited by immune cells such as $\mathrm{T}$ and $\mathrm{B}$ lymphocytes, monocytes, and macrophages. Therefore, these cells play a critical role in immune modulation [35-37]. In the present study, we found that ZPCO treatment resulted in increased numbers of WBCs, lymphocytes, and neutrophils in immunosuppressed rats (Figure 5), which we believe was due to the immunostimulatory effect of ZPCO.

3.7. ZPCO Treatment Results in Increased Plasma Levels of Immune-Related Cytokines in Immunosuppressed Rats. As mentioned earlier, cytokines are crucial in the regulation of inflammatory responses. In particular, $\mathrm{TNF}-\alpha$, which is produced by $\mathrm{T}$ and $\mathrm{B}$ lymphocytes, natural killer cells, and macrophages, modulates inflammation and host defense by inhibiting bacterial infection [42] and suppressing acute stress [41]. INF- $\gamma$ and IL-2 are naturally produced by Thelper cells [43]. While INF- $\gamma$ is a natural immune mediator that activates monocytes/macrophages and promotes the expression of major histocompatibility complex molecules [44], IL-2 enhances T-lymphocyte responses by regulating homeostasis and the differentiation of immature $\mathrm{T}$ lymphocytes into regulatory $\mathrm{T}$ lymphocytes [45]. Lastly, IL-12 is produced by various immune cells, including dendritic cells, 


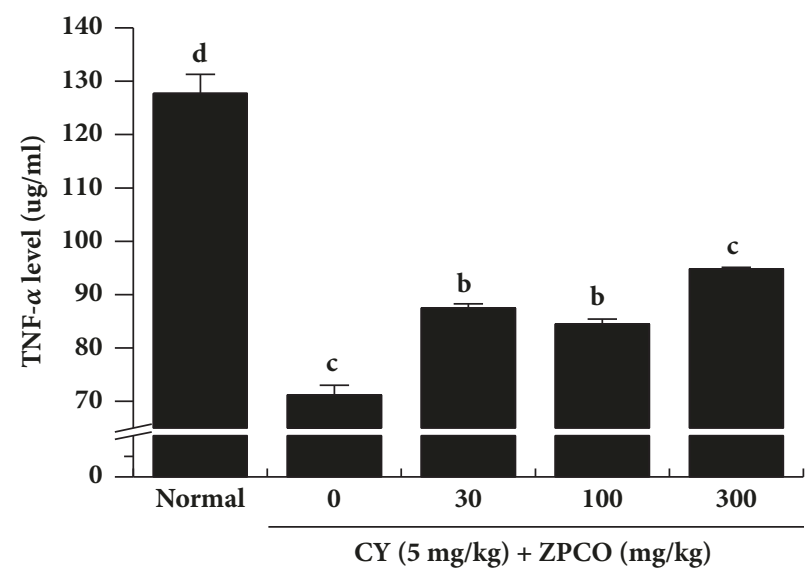

(a)

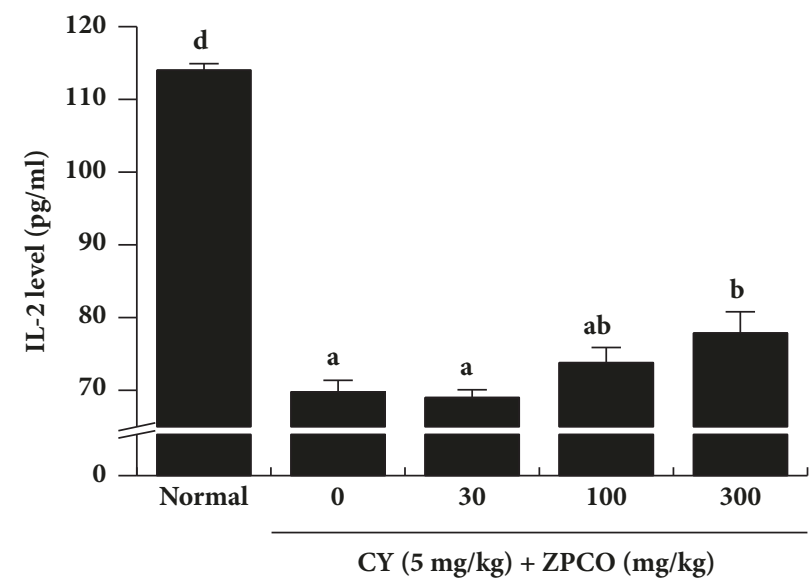

(c)

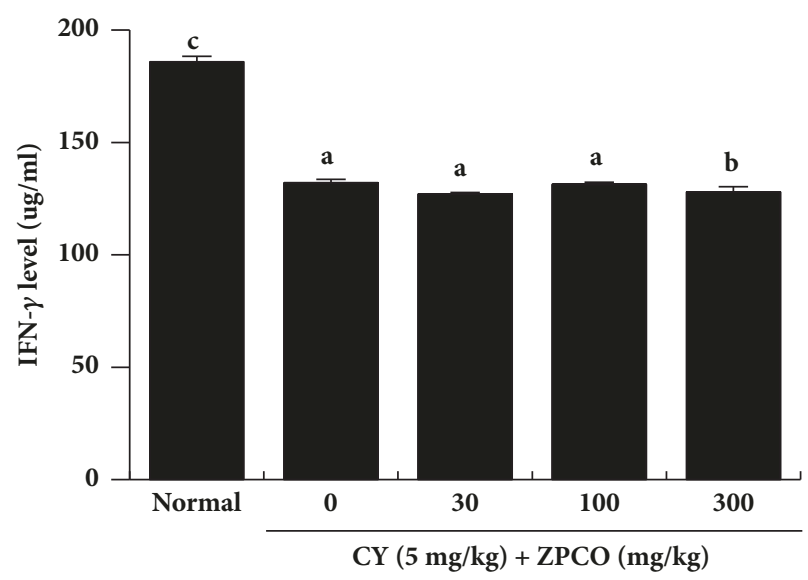

(b)

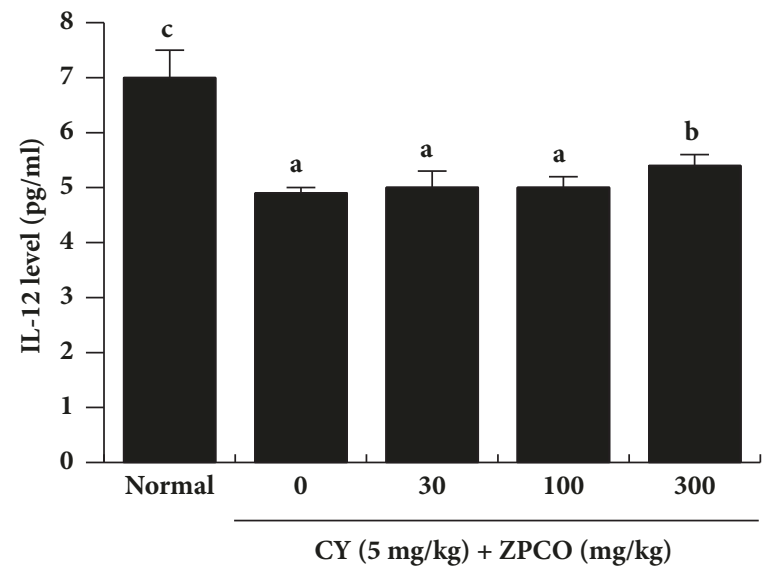

(d)

FIGURE 6: Effect of ZPCO on the plasma levels of immune-related cytokines in the serum of Sprague Dawley (SD) rats. SD rats were treated with saline, cyclophosphamide (CY; $5 \mathrm{mg} / \mathrm{kg} /$ day), and oral ZPCO $(0,30,100$, or $300 \mathrm{mg} / \mathrm{kg} /$ day) once daily for 28 days, after which serum levels of TNF- $\alpha$, IFN- $\gamma$, IL-2, and IL-12 were quantified using ELISA kits. Bars labeled with different superscripts have significantly different values $(\mathrm{P}<0.05$ versus control). Data are presented as means \pm standard errors $(\mathrm{n}=7)$.

macrophages, neutrophils, and human B-lymphoblastoid cells [46] and has been shown to induce the differentiation of naive T lymphocytes into Th1 lymphocytes and to promote the production of TNF- $\alpha$ and IFN- $\gamma$ from T lymphocytes and natural killer cells [47].

Studies are being actively conducted to identify immunomodulators in natural products [48-51]. In the present study, to evaluate the effects of $\mathrm{ZPCO}$ on the expression of immune-related cytokines, we measured the concentrations of TNF- $\alpha$, IFN- $\gamma$, IL-2, and IL-12 in the plasma rats treated with ZPCO and/or Cy (Figure 6). The plasma levels of each cytokine were lower in CY-treated animals than in the normal rats (saline-treated). In addition, among the treated animals, the ZPCO-treated groups typically exhibited significantly higher plasma levels of TNF$\alpha$ and IL- 2 than the non-ZPCO-treated groups. Furthermore, the group treated with $300 \mathrm{mg} / \mathrm{kg}$ ZPCO showed a slight increase in IL-12 levels. suppressed Rats. Figure 7 shows the results obtained via histological analysis of rat spleens. We found that the tissues from the control group showed white pulp surrounding the central vein. Additionally, a marginal zone was observed between the white and red pulps (Figure 7(a)). However, tissues from the CY-treated mice showed an obscured marginal zone. In addition, irregular cell condensates were observed in the red pulp area (Figure $7(\mathrm{~b})$ ). For rats that were treated with ZPCO, especially at a high concentration, a clear marginal zone between the white and red pulps was present, whereas cell condensates were hardly observed (Figure 7(e)). Together, these results indicate that ZPCO stimulated innate and adaptive immunity by facilitating the production of immunity-related cytokines and improving the histopathological characteristics of spleens that had undergone CYinduced damage.

\section{Conclusions}

The results of the in vitro and in vivo studies presented here suggest that ZPCO stimulates the production of certain innate immune cell types as well as specific cytokines and NK 

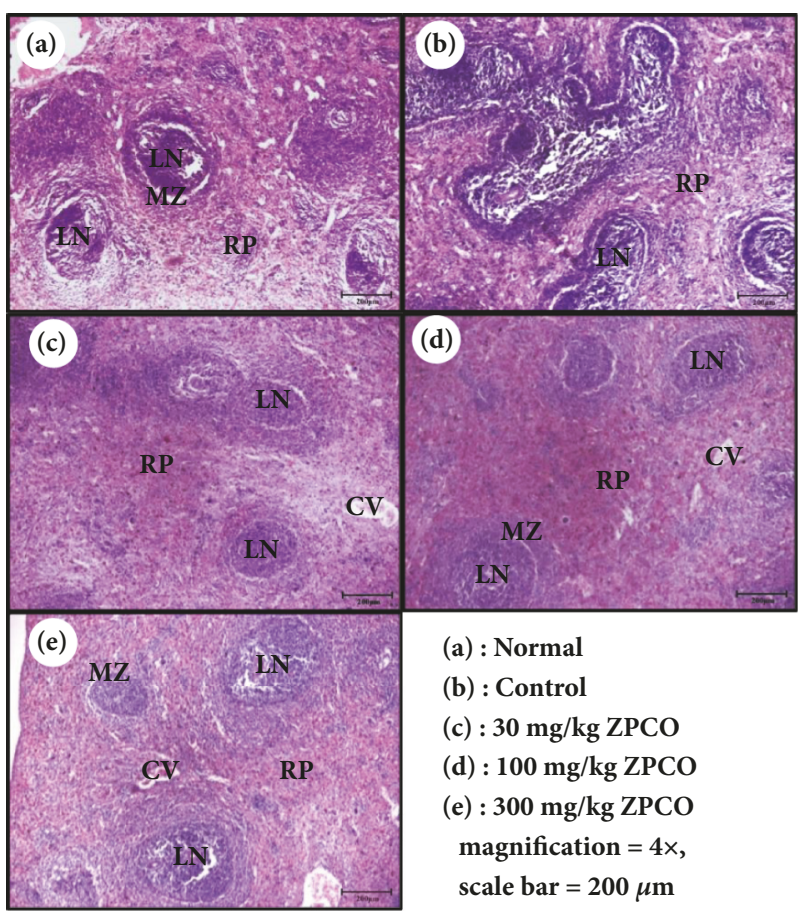
(a) : Normal
(b) : Control
(c) $: 30 \mathrm{mg} / \mathrm{kg}$ ZPCO
(d) $: 100 \mathrm{mg} / \mathrm{kg} \mathrm{ZPCO}$
(e) : $300 \mathrm{mg} / \mathrm{kg} \mathrm{ZPCO}$
magnification $=4 \times$,
scale bar $=200 \mu \mathrm{m}$

FIGURE 7: Effect of ZPCO on immunity-associated spleen damage in Sprague Dawley (SD) rats. SD rats were oral administrated with saline, cyclophosphamide (CY; $5 \mathrm{mg} / \mathrm{kg} /$ day), and ZPCO (0, 30, 100, or $300 \mathrm{mg} / \mathrm{kg} /$ day) once daily for 28 days, after which spleen damage was analyzed histologically. Representative images of the sectioned spleens of (a) normal rats (saline treatment), (b) control rats (treated with only CY), and (c-e) ZPCO-treated rats [treated with CY and (c) $30 \mathrm{mg} / \mathrm{kg}$, (d) $100 \mathrm{mg} / \mathrm{kg}$, or (e) $300 \mathrm{mg} / \mathrm{kg}$ ZPCO]. Scale bar = $200 \mu \mathrm{m}$. CV, central vein; LN, lymph nodule; MZ, marginal zone; $\mathrm{RP}$, red pulp.

cell activity that together improve immunity and host defense under immunosuppressive conditions. These findings indicate that $Z$. schinifolium should be explored as a potential novel immunostimulatory agent for use in functional foods and medicines.

\section{Data Availability}

The data used to support the findings of this study are included within the article.

\section{Conflicts of Interest}

The authors declare that they have no conflicts of interest.

\section{Authors' Contributions}

H. Y. Lee, H. J. Yang, and Y. R. Lee conceived and designed the study. Y. M. Park and Y. H. Lee performed the experiments. Y. G. Kang analyzed the data. H. Y. Lee and Y. R. Lee drafted the manuscript. M. J. Kim and H. J. Yang provided comments and editorial review of the manuscript. H. M. Lee and D. S. Park provided the Complex oil of Zanthoxylum schinifolium and Perilla frutescens seed. All authors read and approved the final manuscript.

\section{Acknowledgments}

This work was supported by "Food Functionality Evaluation program" under the Ministry of Agriculture, Food and Rural Affairs and National Research Council of Science \& Technology (NST) grant by the Korea Government (MSIP) (no. CAP-16-07-KIOM) and Korea Food Research Institute (E0150302-04).

\section{Supplementary Materials}

Supplementary Figure 1: effect of ZPCO on splenocyte viability. Cells were seeded into 96 -well plates, followed by treatment with ZPCO $(0,5,10,30,50,100$, or $300 \mu \mathrm{g} / \mathrm{ml})$. Next, the cells were incubated for $24 \mathrm{~h}$ in a $5 \% \mathrm{CO} 2$ incubator, after which viability was assessed. Bars labeled with different superscripts have significantly different values $(P<0.05)$. Data are presented as means \pm standard errors $(n=3)$. Supplementary Figure 2: effect of ZPCO on the concentration of cytokines in splenocytes. Cells were seeded into 96-well plates, followed by treatment with ZPCO $(0,5,10,30,50$, 100 , or $300 \mu \mathrm{g} / \mathrm{ml}$ ). Next, the cells were incubated for $24 \mathrm{~h}$ in a 5\% CO2 incubator, after which the levels of TNF- $\alpha$, IFN$\gamma$, IL-2, and IL-12 secretion into the culture medium were analyzed. Bars labeled with different superscripts have significantly different values $(\mathrm{P}<0.05$ versus control). Data are presented as means \pm standard errors $(\mathrm{n}=3)$. Supplementary Figure 3: effects of ZPCO on NO production in splenocytes. Splenocytes were incubated with ZPCO $(0,10,30,50,100$, and $300 \mathrm{ug} / \mathrm{ml})$ or cyclophosphamide $(1600 \mu \mathrm{g} / \mathrm{ml})$ for 24 $\mathrm{h}$, and NO concentrations in the culture supernatants were assessed using the Griess assay. Bars labeled with different superscripts have significantly different values $(\mathrm{P}<0.05)$. Data are presented as means \pm standard errors $(n=3)$. (Supplementary Materials)

\section{References}

[1] S. Paik, K. Koh, S. Beak, S. Paek, and J. Kim, “The essential oils from Zanthoxylum schinifolium pericarp induce apoptosis of HepG2 human hepatoma cells through increased production of reactive oxygen species," Biological \& Pharmaceutical Bulletin, vol. 28, no. 5, pp. 802-807, 2005.

[2] R. Li, J.-J. Yang, Y.-X. Shi et al., "Chemical composition, antimicrobial and anti-inflammatory activities of the essential oil from Maqian (Zanthoxylum myriacanthum var. pubescens) in Xishuangbanna, SW China," Journal of Ethnopharmacology, pp. 43-48, 2014.

[3] I.-S. Chen, Y.-C. Lin, I.-L. Tsai et al., "Coumarins and antiplatelet aggregation constituents from Zanthoxylum schinifolium," Phytochemistry, vol. 39, no. 5, pp. 1091-1097, 1995.

[4] S.-U. Chon, B.-G. Heo, Y.-S. Park, D.-K. Kim, and S. Gorinstein, "Total phenolics level, antioxidant activities and cytotoxicity of young sprouts of some traditional Korean salad plants," Plant Foods for Human Nutrition, vol. 64, no. 1, pp. 25-31, 2009. 
[5] B. K. Min, D. G. Hyun, S. Y. Jeong, Y. H. Kim, E. S. Ma, and M. H. Woo, "A new cytotoxic coumarin, 7-[(E)-3/,7/-dimethyl6I-oxo-2I,7I-octadienyl] oxy Coumarin, from the leaves of Zanthoxylum schinifolium," Archives of Pharmacal Research, vol. 34, no. 5, pp. 723-726, 2011.

[6] S. J. Young, D. T. L. Huong, B. KiHwan, K. L. Myung, and H. K. Young, "Monoamine oxidase inhibitory coumarin from Zanthoxylum schinifolium," Planta Medica, vol. 68, no. 1, pp. 84-85, 2002.

[7] L. H. Cao, Y. J. Lee, D. G. Kang, J. S. Kim, and H. S. Lee, "Effect of Zanthoxylum schinifolium on TNF- $\alpha$-induced vascular inflammation in human umbilical vein endothelial cells," Vascular Pharmacology, vol. 50, no. 5-6, pp. 200-207, 2009.

[8] P. S. Haddad, G. A. Azar, S. Groom, and M. Boivin, "Natural Health Products, Modulation of Immune Function and Prevention of Chronic Diseases," Evidence-Based Complementary and Alternative Medicine, vol. 2, 8 pages, 2005.

[9] D. N. Khalil, E. L. Smith, R. J. Brentjens, and J. D. Wolchok, "The future of cancer treatment: Immunomodulation, CARs and combination immunotherapy," Nature Reviews Clinical Oncology, vol. 13, no. 5, pp. 273-290, 2016.

[10] L. Zitvogel, L. Apetoh, F. Ghiringhelli, and G. Kroemer, "Immunological aspects of cancer chemotherapy," Nature Reviews Immunology, vol. 8, no. 1, pp. 59-73, 2008.

[11] H. S. Kim, J. Y. Kim, J. S. Kang et al., "Cordlan polysaccharide isolated from mushroom Cordyceps militaris induces dendritic cell maturation through toll-like receptor 4 signalings," Food and Chemical Toxicology, vol. 48, no. 7, pp. 1926-1933, 2010.

[12] S. P. Wasser, "Medicinal mushrooms as a source of antitumor and immunomodulating polysaccharides," Applied Microbiology and Biotechnology, vol. 60, no. 3, pp. 258-274, 2002.

[13] I. A. Schepetkin and M. T. Quinn, "Botanical polysaccharides: macrophage immunomodulation and therapeutic potential," International Immunopharmacology, vol. 6, no. 3, pp. 317-333, 2006.

[14] D. A. Hume, "The mononuclear phagocyte system," Current Opinion in Immunology, vol. 18, no. 1, pp. 49-53, 2006.

[15] A. H. Klimp, E. G. E. De Vries, G. L. Scherphof, and T. Daemen, "A potential role of macrophage activation in the treatment of cancer," Critical Review in Oncology/Hematology, vol. 44, no. 2, pp. 143-161, 2002.

[16] G. J. Pass, D. Carrie, M. Boylan et al., "Role of hepatic cytochrome P450s in the pharmacokinetics and toxicity of cyclophosphamide: studies with the hepatic cytochrome P450 reductase null mouse," Cancer Research, vol. 65, no. 10, pp. 42114217, 2005.

[17] D. N. Tripathi and G. B. Jena, "Intervention of astaxanthin against cyclophosphamide-induced oxidative stress and DNA damage: A study in mice," Chemico-Biological Interactions, vol. 180, no. 3, pp. 398-406, 2009.

[18] K. P. Singh, R. K. Gupta, H. Shau, and P. K. Ray, "Effect of ASTAz 7575 (INN maphosphamide) on human lymphokine-activated killer cell induction," Immunopharmacology and Immunotoxicology, vol. 15, no. 5, pp. 525-538, 1993.

[19] D. O. Adams and T. A. Hamilton, "The Cell Biology of Macrophage Activation," Annual Review of Immunology, vol. 2, no. 1, pp. 283-318, 1984.

[20] Y. Zhou, X. Chen, R. Yi et al., "Immunomodulatory effect of tremella polysaccharides against cyclophosphamide-induced immunosuppression in mice," Molecules, vol. 23, no. 2, 2018.
[21] H.-C. Woo, B.-K. Shin, I. Cho, H. Koo, M. Kim, and J. Han, "Anti-obesity effect of carbon dioxide supercritical fluid extracts of Panax ginseng C. A. Meyer," Journal of the Korean Society for Applied Biological Chemistry, vol. 54, no. 5, pp. 738-743, 2011.

[22] M. Oh and M. S. Chung, "Effects of Oils and Essential Oils from Seeds of Zanthoxylum schinifolium against Foodborne Viral Surrogates," Evidence-Based Complementary and Alternative Medicine, vol. 2014, Article ID 135797, 6 pages, 2014.

[23] M. La Guardia, S. Giammanco, D. Di Majo et al., "Omega 3 fatty acids: biological activity and effects on human health," Panminerva Medica, vol. 47, no. 4, pp. 245-57, 2005.

[24] P. C. Calder, "Functional roles of fatty acids and their effects on human health," Journal of Parenteral and Enteral Nutrition, vol. 39, supplement 1, pp. 18S-32S, 2015.

[25] A. T. Vella and J. P. McAleer, "Understanding How Lipopolysaccharide Impacts CD4 T-Cell Immunity," Critical Reviews ${ }^{\mathrm{TM}}$ in Immunology, vol. 28, no. 4, pp. 281-299, 2008.

[26] S. Mburu, J. L. Marnewick, A. Abayomi, and H. Ipp, "Modulation of LPS-Induced CD4+ T-Cell Activation and Apoptosis by Antioxidants in Untreated Asymptomatic HIV Infected Participants: An In Vitro Study," Clinical and Developmental Immunology, vol. 2013, Article ID 631063, 9 pages, 2013.

[27] A. J. Ulmer, H.-D. Flad, T. Rietschel, and T. Mattern, "Induction of proliferation and cytokine production in human T lymphocytes by lipopolysaccharide (LPS)," Toxicology, vol. 152, no. 1-3, pp. 37-45, 2000.

[28] D. Xu, M. Komai-Koma, and F. Y. Liew, "Expression and function of Toll-like receptor on T cells," Cellular Immunology, vol. 233, no. 2, pp. 85-89, 2005.

[29] D. Kabelitz, "Expression and function of Toll-like receptors in T lymphocytes," Current Opinion in Immunology, vol. 19, no. 1, pp. 39-45, 2007.

[30] G. Zeng, Y. Ju, H. Shen, N. Zhou, and L. Huang, "Immunopontentiating activities of the purified polysaccharide from evening primrose in $\mathrm{H} 22$ tumor-bearing mice," International Journal of Biological Macromolecules, vol. 52, no. 1, pp. 280-285, 2013.

[31] J. Conniot, J. M. Silva, J. G. Fernandes et al., "Cancer immunotherapy: nanodelivery approaches for immune cell targeting and tracking," Frontiers in Chemistry, vol. 2, 2014.

[32] A. Krug, A. R. French, W. Barchet et al., "TLR9-dependent recognition of MCMV by IPC and DC generates coordinated cytokine responses that activate antiviral NK cell function," Immunity, vol. 21, no. 1, pp. 107-119, 2004.

[33] R. Medzhitov and C. A. Janeway Jr., "Innate immunity: Impact on the adaptive immune response," Current Opinion in Immunology, vol. 9, no. 1, pp. 4-9, 1997.

[34] L. Moretta, C. Bottino, C. Cantoni et al., "Human natural killer cell function and receptors," Current Opinion in Pharmacology, vol. 1, no. 4, pp. 387-391, 2001.

[35] B. B. Aggarwal, "Signalling pathways of the TNF superfamily: a double-edged sword," Nature Reviews Immunology, vol. 3, no. 9, pp. 745-756, 2003.

[36] O. Boyman and J. Sprent, "The role of interleukin-2 during homeostasis and activation of the immune system," Nature Reviews Immunology, vol. 12, no. 3, pp. 180-190, 2012.

[37] P. L. Lin, H. L. Plessner, N. N. Voitenok, and J. L. Flynn, "Tumor necrosis factor and tuberculosis," Journal of Investigative Dermatology Symposium Proceedings, vol. 12, no. 1, pp. 22-25, 2007.

[38] D. F. Tough, S. Sun, and J. Sprent, "T cell stimulation in vivo by lipopolysaccharide (LPS)," The Journal of Experimental Medicine, vol. 185, no. 12, pp. 2089-2094, 1997. 
[39] C.-S. Hsieh, S. E. Macatonia, C. S. Tripp, S. F. Wolf, A. O’Garra, and K. M. Murphy, "Development of TH1 CD $4^{+} \mathrm{T}$ cells through IL-12 produced by Listeria-induced macrophages," Science, vol. 260, no. 5107, pp. 547-548, 1993.

[40] Badovinac, Trajkovic, and Mostarica-Stojkovic, "Nitric oxide promotes growth and major histocompatibility complex- unrestricted cytotoxicity of interleukin-2-activated rat lymphocytes," Scandinavian Journal of Immunology, vol. 52, no. 1, pp. 62-70, 2000.

[41] T. J. Connor, C. Brewer, J. P. Kelly, and A. Harkin, "Acute stress suppresses pro-inflammatory cytokines TNF- $\alpha$ and IL$1 \beta$ independent of a catecholamine-driven increase in IL-10 production," Journal of Neuroimmunology, vol. 159, no. 1-2, pp. 119-128, 2005.

[42] C. Giai, C. Gonzalez, C. Ledo et al., "Shedding of tumor necrosis factor receptor 1 induced by protein A decreases tumor necrosis factor alpha availability and inflammation during systemic Staphylococcus aureus infection," Infection and Immunity, vol. 81, no. 11, pp. 4200-4207, 2013.

[43] G. E. Kaiko, J. C. Horvat, K. W. Beagley, and P. M. Hansbro, "Immunological decision-making: how does the immune system decide to mount a helper T-cell response?" The Journal of Immunology, vol. 123, no. 3, pp. 326-338, 2008.

[44] K. Schroder, P. J. Hertzog, and T. Ravasi, "Interferon-gamma: an overview of signals, mechanisms and functions," Journal of Leukocyte Biology, vol. 75, no. 2, pp. 163-89, 2004.

[45] P. Zhang, S.-K. Tey, M. Koyama et al., "Induced regulatory T cells promote tolerance when stabilized by rapamycin and IL-2 in vivo," The Journal of Immunology, vol. 191, no. 10, pp. 52915303, 2013.

[46] S. E. Dorman and S. M. Holland, "Interferon- $\gamma$ and interleukin12 pathway defects and human disease," Cytokine \& Growth Factor Reviews, vol. 11, no. 4, pp. 321-333, 2000.

[47] W. T. Watford, M. Moriguchi, A. Morinobu, and J. J. O'Shea, "The biology of IL-12: coordinating innate and adaptive immune responses," Cytokine \& Growth Factor Reviews, vol. 14, no. 5, pp. 361-368, 2003.

[48] Q. Fang, J.-F. Wang, X.-Q. Zha, S.-H. Cui, L. Cao, and J.P. Luo, "Immunomodulatory activity on macrophage of a purified polysaccharide extracted from Laminaria japonica," Carbohydrate Polymers, vol. 134, Article ID 10172, pp. 66-73, 2015.

[49] J. Lee, J. W. Choi, J. K. Sohng, R. P. Pandey, and Y. I. Park, "The immunostimulating activity of quercetin 3-O-xyloside in murine macrophages via activation of the ASK1/MAPK/NF- $\kappa \mathrm{B}$ signaling pathway," International Immunopharmacology, vol. 31, pp. 88-97, 2016.

[50] X. Song, T. Ren, Z. Zheng et al., "Anti-tumor and immunomodulatory activities induced by an alkali-extracted polysaccharide BCAP-1 from Bupleurum chinense via NF- $\kappa$ B signaling pathway," International Journal of Biological Macromolecules, vol. 95, pp. 357-362, 2017.

[51] H. Wang, T. Gao, Y. Du et al., "Anticancer and immunostimulating activities of a novel homogalacturonan from Hippophae rhamnoides L. berry," Carbohydrate Polymers, vol. 131, pp. 288296, 2015. 


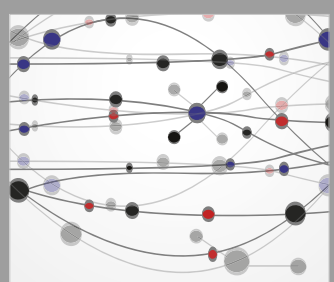

The Scientific World Journal
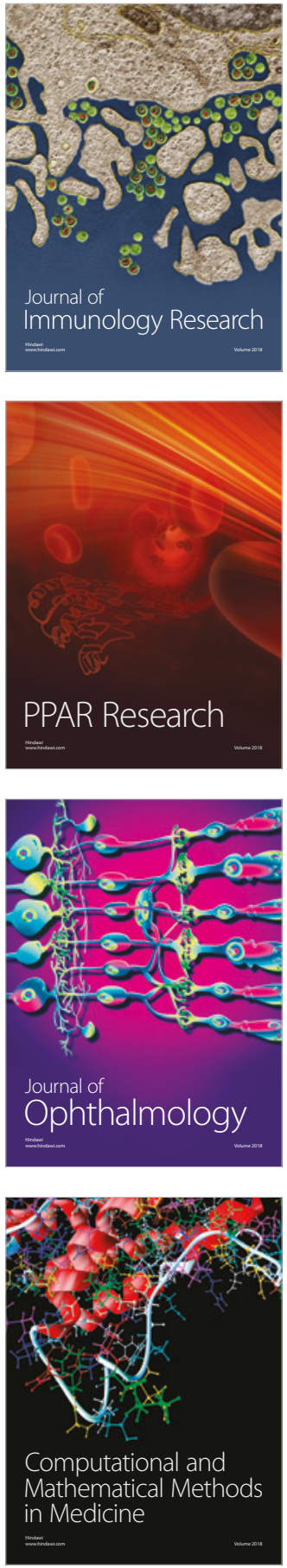

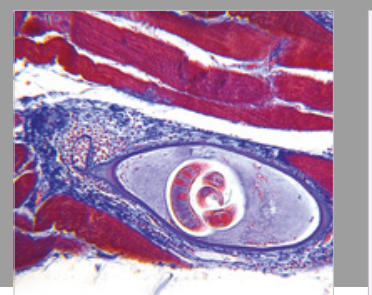

Gastroenterology Research and Practice

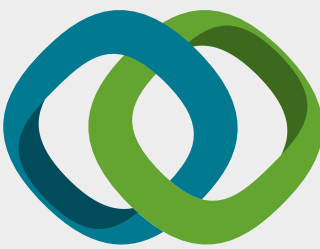

\section{Hindawi}

Submit your manuscripts at

www.hindawi.com
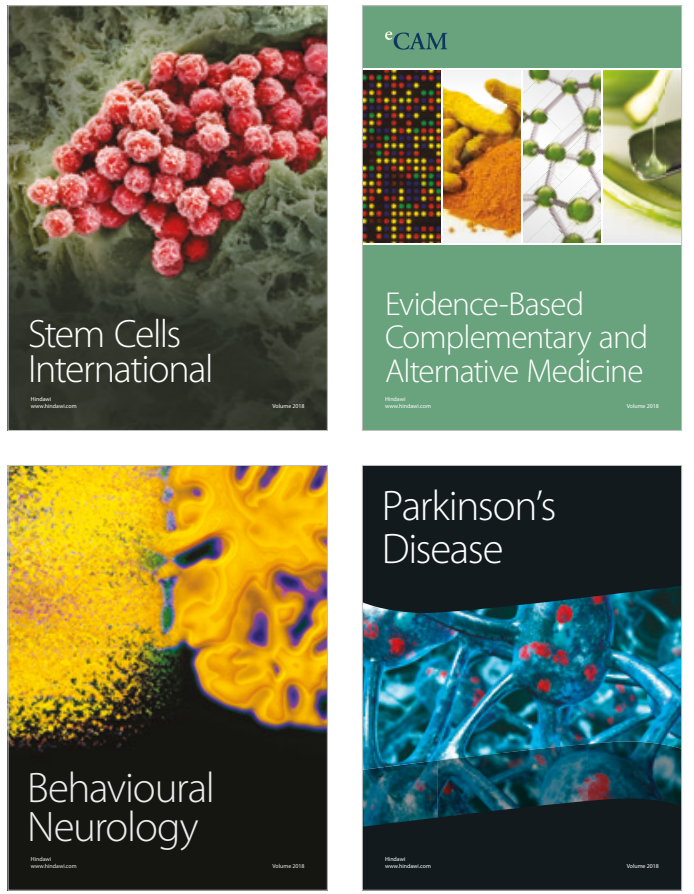

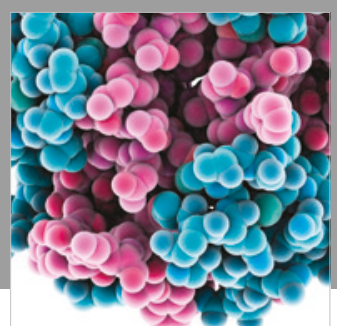

ournal of

Diabetes Research

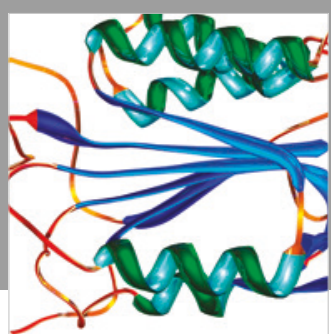

Disease Markers
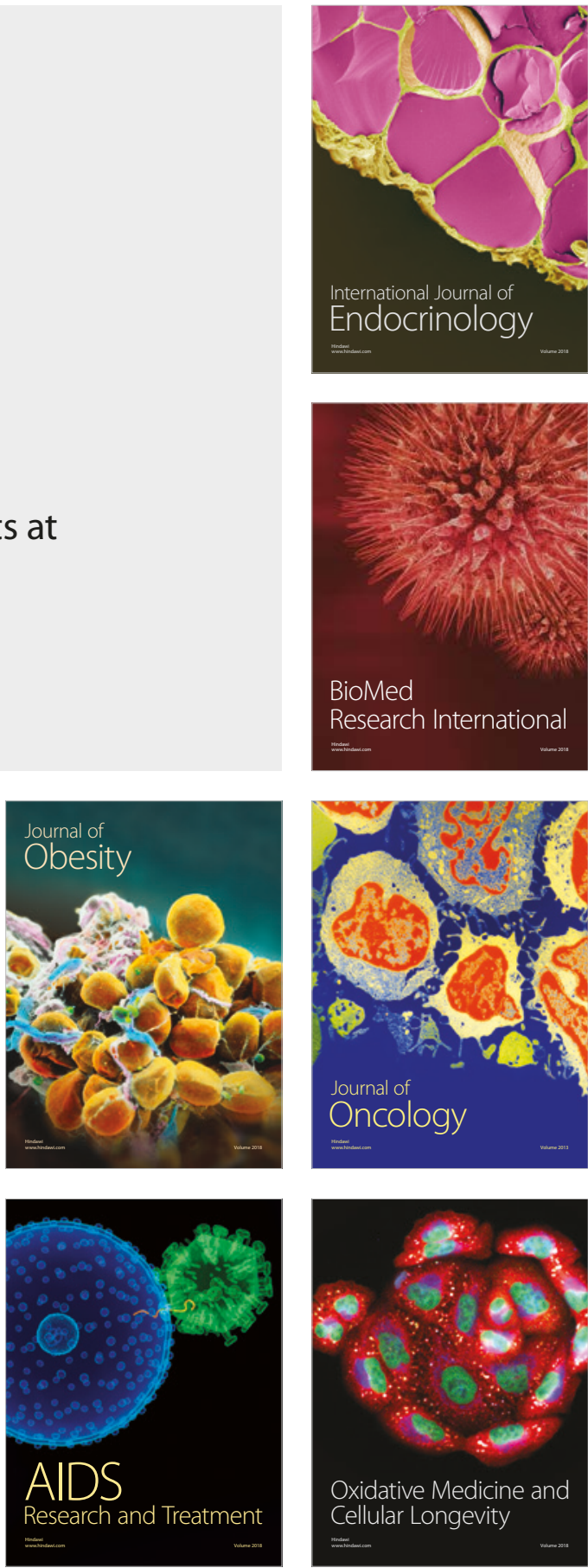